\title{
Effect of Post-Weld Aging Temperature on Microstructure and Mechanical Properties of Weld Metal of 15-5 PH Stainless Steel
}

\author{
Jingpeng Niu, Bing Cui (D), Huijin Jin, Jialing Yan, Wei Meng, Chunying Min, and Dong Xu
}

(Submitted March 9, 2020; in revised form September 7, 2020; accepted September 19, 2020; published online October 21, 2020)

\begin{abstract}
This study is an attempt to correlate the microstructure and mechanical properties of weld metal of commercial $15 \mathrm{Cr}-5 \mathrm{Ni}$ precipitation-hardening stainless steel at different post-weld treatments. The weld metal is conducted by gas tungsten arc welding, and post-weld aging is performed at three different temperatures, viz. $580^{\circ} \mathrm{C}, 600{ }^{\circ} \mathrm{C}$ and $620^{\circ} \mathrm{C}$. After post-weld aging treatment, the microstructure and mechanical properties of weld metals are investigated by OM, SEM, EDS, EBSD and impact tester. The results indicate that microstructure of weld metals by post-weld aging treatment consists predominately of martensite, reversion austenite and copper-rich phase. The amount of austenite and the size of copper-rich phase increase with increase in the post-weld aging temperature. The tensile strength of weld metals first increases and then decreases with the increasing of post-weld aging temperature. The former is due to the size and distribution of copper-rich phase, and the latter is due to the increasing of amount of reversion austenite.
\end{abstract}

Keywords copper-rich phase, mechanical properties, post-weld aging temperature, reversion austenite, weld metal

\section{Introduction}

Precipitation-hardened stainless steel is a new type of steel developed during the second world war due to the need of war and then gradually developed into three types: martensite type, semi-austenitic type and austenitic type. They are mostly in $\mathrm{Cr}$, $\mathrm{Ni}$ and then adding precipitation hardening stainless steel elements such as $\mathrm{Al}, \mathrm{Cu}, \mathrm{Ti}, \mathrm{Mo}$ and $\mathrm{Nb}$ through hightemperature solid solution treatment, make the alloy elements can dissolve into the matrix and supersaturated solid solution after cooling, and then in the appropriate temperature aging treatment, decomposition of supersaturated solid solution, intermetallic compounds, carbide precipitation, such as dispersion precipitate hardening effect, and this kind of steel heat treatment is simpler, such as the $15-5 \mathrm{PH}$ stainless steel has good corrosion resistance, high strength and good processing properties. A simple one-step aging treatment gives the $15-5 \mathrm{PH}$ high strength and good plasticity and toughness, which is widely used in key components in the aerospace field (Ref 1-7). Aging treatment is the main strengthening method of martensitic precipitation hardening stainless steel. High strength and

\footnotetext{
Jingpeng Niu, Bing Cui, Wei Meng, Chunying Min, and Dong Xu, Anhui Province Key Laboratory of Metallurgy Engineering and Resources Recycling (Anhui University of Technology), Ma'anshan 243002, China; Huijin Jin, State Key Laboratory of Nonlinear Mechanics, Institute of Mechanics, Chinese Academy of Sciences, Beijing 100190, China; and Jialing Yan, East China Electric Power Test and Research Institute of China Datang Corporation Science and Technology Research Institute, Hefei 23000, China. Contact e-mails: brazingcb@163.com and frank@shu.edu.cn.
}

high toughness are obtained by precipitation hardening phase such as $\mathrm{Cu}$-rich phase, $\mathrm{NbC}$ and $\mathrm{M}_{23} \mathrm{C}_{6}$ at $450-620{ }^{\circ} \mathrm{C}$, so as to meet the application requirements of different occasions. However, the research mainly concentrated on the solution of this kind of steel and the mechanical properties after short-term aging treatment and organization transformation, including tensile properties, impact performance, martensite phase transformation, precipitation of copper-rich phase and spinodal decomposition of martensitic matrix (Ref 8-11), have comparatively detailed research, however, those studies only concentrated on the general changes of copper-rich phase or mechanical properties. Few studies regarding the formation of reversed austenite during post-weld aging treatment and its influence on the weld metal of $15-5 \mathrm{PH}$ have been reported. In order to study the maximum operating temperature of weld metal of 15-5PH stainless steel, and to understand the change of its structure and performance during service, it can provide reference for the application of petrochemical and nuclear engineering materials. Therefore, this study mainly observed and analyzed the microstructure transformation process and mechanical property changes of $15-5 \mathrm{PH}$ stainless steel after direct post-weld aging heat treatment after welding.

\section{Experiment Procedure}

The chemical composition of the deposited metal of 15-5PH stainless steel and ER630 welding wire (Ref 8) is shown in Table 1. The welding machine is AMET hot and cold wire TIG welding machine. The welding process heat input is $15 \mathrm{~kJ} \mathrm{~cm}^{-1}$, interpass temperature is $\leq 150{ }^{\circ} \mathrm{C}$, and shielding gas is high-purity argon. The size of the test plate is $16 \mathrm{~mm} \times 150 \mathrm{~mm} \times 300 \mathrm{~mm}$ and with single- $\mathrm{V}$ groove weld. The samples are welded in the solution treated condition and then subjected to different post-weld aging treatments. Before welding, wipe the test plate clean with acetone. The blank 
samples are subjected to post-weld aging treatment at $580{ }^{\circ} \mathrm{C} \times 4 \mathrm{~h}, 600{ }^{\circ} \mathrm{C} \times 4 \mathrm{~h}$ and $620{ }^{\circ} \mathrm{C} \times 4 \mathrm{~h}$, respectively. The heat treatment furnace adopted is the air heating box-type furnace in the central test platform of the general research institute of iron and steel, which is installed in the temperature furnace, and then air cooling (AC) is removed after heat treatment. After post-weld aging treatment, samples are refined to finished samples. After grinding and polishing, the metallographic samples are corroded by ferric chloride. The metal phase components of the weld are analyzed by optical microscope Leicamef-4M, Hitachi S-4300 cold field emission electron microscope and its own EDS, and the fracture morphology of the weld is observed and analyzed. The fine microstructure and precipitated phase of the weld are observed by $\mathrm{H}-800$ and high-resolution transmission electron microscopy. The TEM samples are prepared by double spray electrolysis thinning. The electrolyte is $8 \%$ perchlorate alcohol solution. The weld metal is tested for V-shaped impact performance at $-20{ }^{\circ} \mathrm{C}$ with the sample size of $10 \mathrm{~mm} \times 10$ $\mathrm{mm} \times 55 \mathrm{~mm}$. Using electron backscattering diffraction (electron backscattered diffraction, EBSD) is carried out on the sample surface, and its large angle in HKL analysis software distribution and reverse change the content of austenite grain boundary and evaluation analysis, respectively, EBSD sample should be with $10 \%$ perchlorate solution electrolytic polishing, scanning the area for $150 \mathrm{~mm} \times 150 \mathrm{~mm}$, and step length is $0.15 \mathrm{~mm}$.

\section{Results and Discussions}

\subsection{Microstructure Observation}

Figure 1 shows the metallographic structure of weld metal samples aged for $4 \mathrm{~h}$ at different post-weld aging treatments. It can be seen from Fig. 1(a), (b) and (c) that a small number of austenitic white pools are formed at grain boundaries and between dendrites, and the number and size of austenitic white pools increase with increase in the post-weld aging temperature. This is mainly due to the rapid cooling rate during the welding solidification process and the severe segregation of alloying elements between dendrites, resulting in the high alloy composition in this region and the decrease of Ms point, providing conditions for the formation of austenitic white pool (Ref 12). And grain boundary exist many flaw area which have high energy, with the increase of post-weld aging temperature, can be spread through the enrichment of some of the austenite formed elements (such as $\mathrm{C}, \mathrm{Ni}$ ), also for the formation of austenitic white pool (Ref 13), as indicated by the arrows, provides the conditions to make the reversal austenite of martensitic transformation start Ms to below room temperature, in the subsequent cooling process of reverse austenite is retained. Reverse austenite along martensite lath and block distribution, reverse austenite as a soft exists in martensitic matrix, certainly can relax in the deformation of the boundary due to the stress concentration caused by dislocation plug product, at the same time, the crack in the plastic phase transmission need to absorb more energy, therefore play a block on the propagation of the crack effect, increased the matrix of crack propagation resistance, make the weld metal has good toughness, so it is very beneficial to improve the toughness of the material (Ref 4).

Figure 2 shows SEM images for the post-weld aging temperature of $580{ }^{\circ} \mathrm{C}, 600{ }^{\circ} \mathrm{C}$ and $620{ }^{\circ} \mathrm{C}$. Under scanning electron microscope with high magnification some small spherical particles can be found, through the spectrum analysis can find its $\mathrm{Nb}$ content is very high, in stainless steel, the sediment is mainly composed of $\mathrm{NbC}$ generated by the $\mathrm{Nb}$ carbides, $(\mathrm{Nb}, \mathrm{Ti}) \mathrm{N}$ of nitride and $\mathrm{Fe}_{2} \mathrm{Nb}$ (Laves phase). And $(\mathrm{Nb}, \mathrm{Ti}) \mathrm{N}$ is usually rectangular particle, Laves phase is usually accompanied by topology (topologically close packed (TCP) structure) of $\mathrm{A}_{2} \mathrm{~B}$ type of intermetallic compounds, Laves phase can also be observed under the scanning electron microscopy (SEM), but its size is bigger than $\mathrm{NbC}$. Yamamoto et al. (Ref 14) believed that Laves phase could be precipitated in $\mathrm{Fe}-\mathrm{Cr}-\mathrm{Ni}$-Nb martensite stainless steel only when $\mathrm{Nb}$ content is greater than or equal to $1 \mathrm{wt} \%$. In this paper, considering that

Table 1 Chemical composition of custom 450 steel and deposited metal (mass fraction/\%)

\begin{tabular}{llllllll}
\hline & $\mathbf{C}$ & Mn & Cr & Ni & Cu & Nb & Fe \\
\hline 15-5PH & 0.037 & 0.5 & 14.44 & 6.4 & 1.62 & 0.59 \\
ER630 deposited metal & 0.012 & 0.61 & 16.30 & 5.12 & 3.38 & 0.24 & Bal. \\
\hline
\end{tabular}
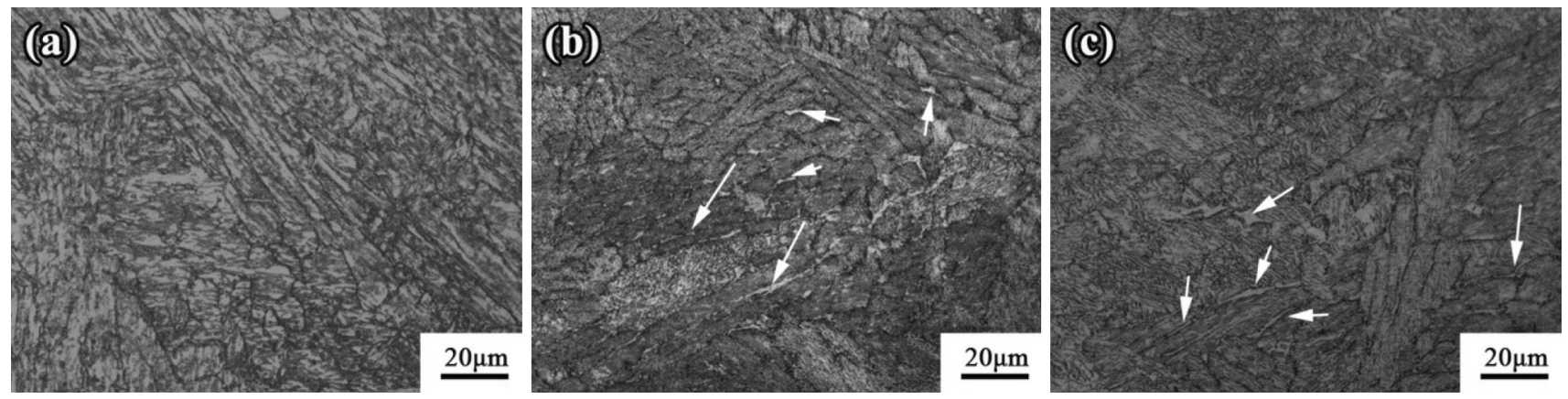

Fig. 1 Microstructure images of weld metal after aging-treated at $580{ }^{\circ} \mathrm{C} \mathrm{(a),} 600{ }^{\circ} \mathrm{C}(\mathbf{b})$ and $620{ }^{\circ} \mathrm{C}(\mathbf{c})$ for $4 \mathrm{~h}$ 

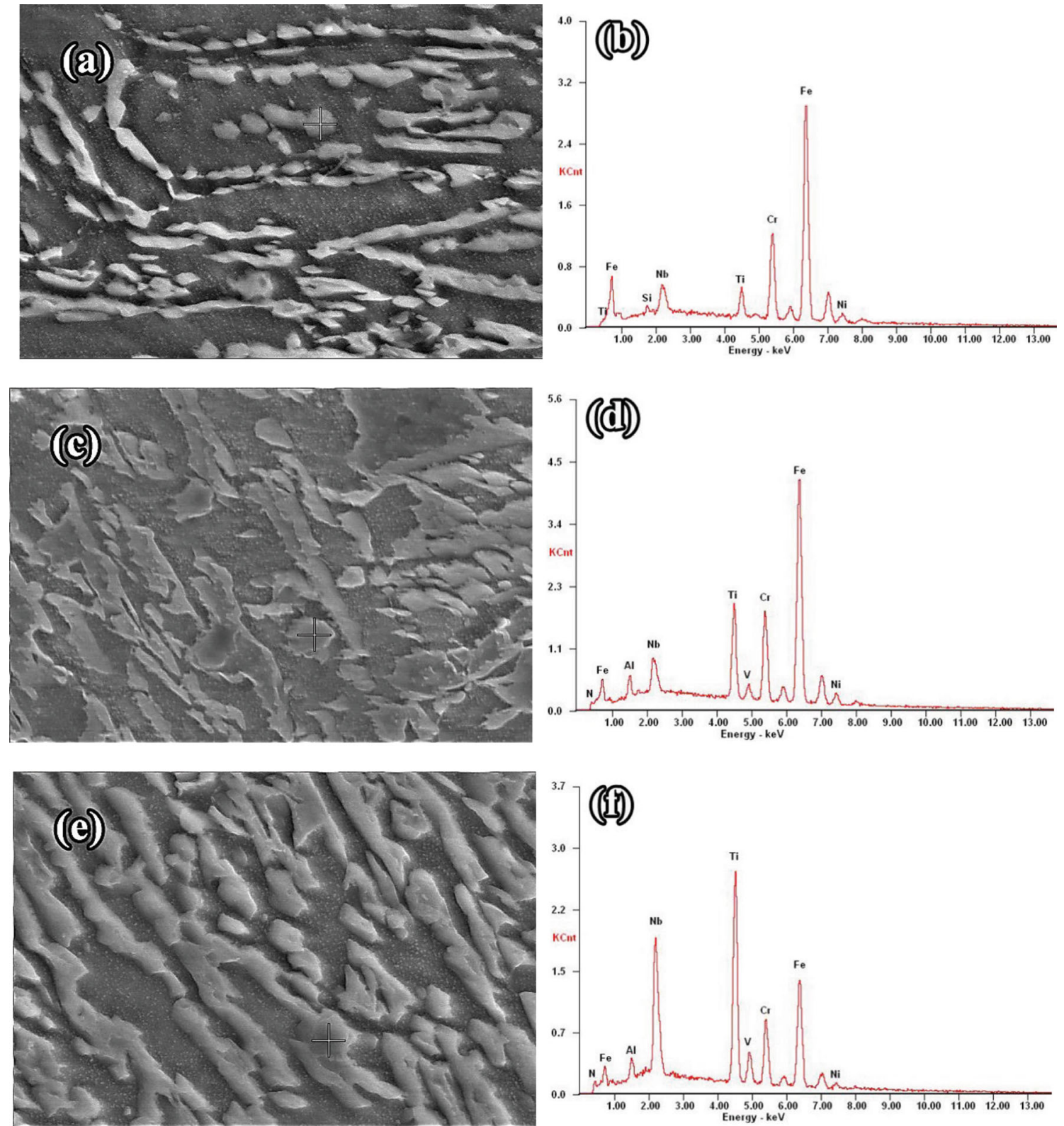

Fig. 2 SEM images and EDS analysis of weld metal after aging-treated at $580{ }^{\circ} \mathrm{C}$ for (a) (b); $600{ }^{\circ} \mathrm{C}$ for (c) (d) and $620{ }^{\circ} \mathrm{C}$ for (e) (f)

the content of $\mathrm{Nb}$ is only 0.24 wt.\%, it can be seen from EDS analysis that the content of $\mathrm{Nb}$ is several times higher than that of the matrix, while $\mathrm{C}$ and $\mathrm{Nb}$ have a strong binding ability (Ref 15). Therefore, the spherical particles found under scanning electron microscopy are $\mathrm{NbC}$ particles, and $\mathrm{NbC}$ particles grow gradually with the increase of post-weld aging temperature, weakening the strengthening effect (Ref 16).

\subsection{TEM Analysis}

Figure 3 shows TEM images of the samples aged for $4 \mathrm{~h}$ at different post-weld aging treatments. The observation by transmission electron microscopy showed that the matrix structure of weld metal after post-weld aging treatment at different temperatures is lath martensite + reverse austenite, and the reverse austenite is mostly formed in strip thin film form, while a small amount is precipitated in block form. It can be seen from Fig. 3 that with the increase of post-weld aging temperature, the content of reversed austenite increases, but it is all distributed on martensite slab boundary, which is beneficial to improve the toughness of high-strength martensite. Because it can be used not only as an obstacle to prevent the crack propagation between martensite, but also to reduce the stress concentration caused by the front end of dislocation when the slat is densely arranged. Residual austenite is distributed around lamellar martensite, which may also mitigate defects in twin martensite (Ref 4).

Figure 4 shows TEM and HRTEM images of $\mathrm{Cu}$ precipitated phase after post-weld aging temperature at $580{ }^{\circ} \mathrm{C}$, $600{ }^{\circ} \mathrm{C}$ and $620{ }^{\circ} \mathrm{C}$. As shown in Fig. 4, after post-weld aging treatment at $580{ }^{\circ} \mathrm{C}, 600{ }^{\circ} \mathrm{C}$ and $620^{\circ} \mathrm{C}$ a large number of copper-rich phase is precipitated in the grains, and the precipitated phase exist as the strengthening phase (Ref 17$25)$. When the temperature is low, the copper-rich phase is not completely dissolved, and the co-lattice relationship with the 

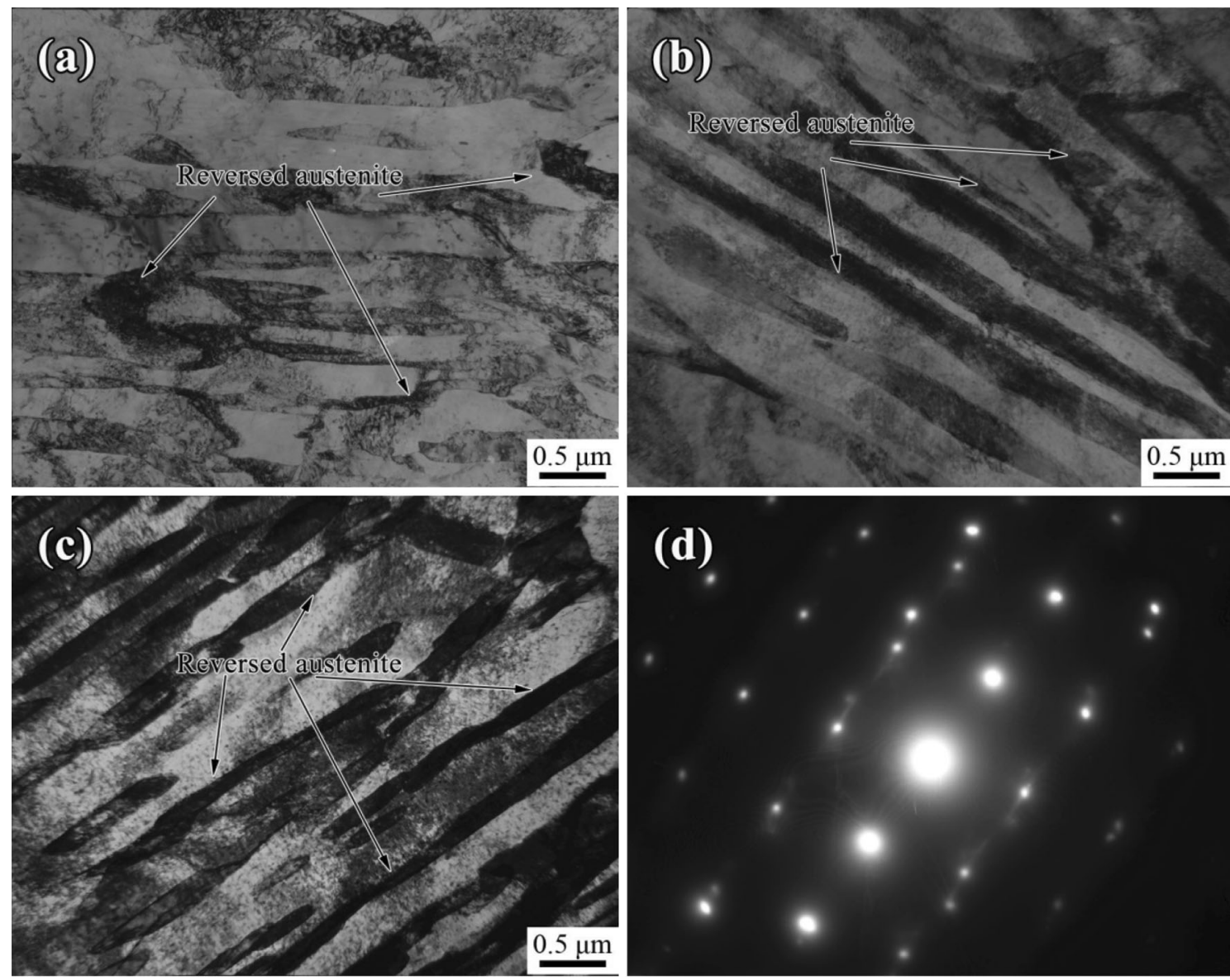

Fig. 3 TEM images of weld metal after aging-treated at $580{ }^{\circ} \mathrm{C}(\mathbf{a}), 600^{\circ} \mathrm{C}(\mathbf{b})$ and $620{ }^{\circ} \mathrm{C}$ (c) for $4 \mathrm{~h}$, (d) the selection diffraction spots of (b)

matrix is not easy to observe. With the increase of post-weld aging temperature, the content of $\mathrm{C}$ and alloying elements in martensite decreases continuously due to the accelerated precipitation of alloy carbides. At the same time, the precipitated phase gradually gathered and grew, and the copper-rich phase changed from the common lattice phase to the noncommon lattice phase (Ref 19, 22, 24) (Fig. 4b). The study found that with increase in the post-weld aging temperature, the size of copper-rich phase increased and then decreased, which is mainly caused by the accumulation and growth of copperrich phase at $620{ }^{\circ} \mathrm{C}$. After post-weld aging at $580{ }^{\circ} \mathrm{C}$ for $4 \mathrm{~h}$, the copper-rich phase is spherical (Fig. 4a). With increase in the post-weld aging temperature, the copper-rich phase accumulated and grew and dispersed after post-weld aging temperature at $600{ }^{\circ} \mathrm{C}$ for $4 \mathrm{~h}$ (Fig. 4b).

\subsection{EBSD Analysis}

Reverse austenitic transformation has both good and bad effects on the properties of steel. Figure 5 shows the electron backscatter diffraction mass diagram of the weld metal. The gray substrate represents the microstructure of the bodycentered cubic structure (here represents the bainitic ferrite structure), while the white color represents the face-centered cubic structure (residual austenite structure). The analysis software of EBSD is used to calculate the reversed austenite content. With the increase of post-weld aging temperature, the reversed austenite content is $0.1 \%, 19 \%$ and $23.4 \%$, respec- tively. The results showed that the content of reversed austenite increased with increase in the post-weld aging temperature, and the content of reversed austenite increased sharply after post-weld aging temperature at $600{ }^{\circ} \mathrm{C}$, while the content of reversed austenite increased by $23.3 \%$ after postweld aging temperature at $620{ }^{\circ} \mathrm{C}$ compared with that at $580{ }^{\circ} \mathrm{C}$.

\subsection{Mechanical Properties}

Post-weld aging temperature has an important influence on the strength of weld metal. The tensile strength of weld metals first increases and then decreases with the increasing of postweld aging temperature, while the yield strength shows a trend of gradual decline as shown in Fig. 6. Combined with the previous analysis, it can be seen that the copper-rich phase is small and diffusedly distributed at $600{ }^{\circ} \mathrm{C}$, which has a certain strengthening effect. The tensile strength at $600{ }^{\circ} \mathrm{C}$ is higher than the other two. In addition, it is found that the yield strength curve with post-weld aging temperature rising from 580 to $600{ }^{\circ} \mathrm{C}$ had a steeper slope than the yield strength curve with post-weld aging temperature rising from 600 to $620^{\circ} \mathrm{C}$. Through the previous tissue analysis, it is found that this is mainly due to the high residual austenite content in the tissues after post-weld aging temperature at $600{ }^{\circ} \mathrm{C}$.

As the post-weld aging temperature increases, the impact toughness of the weld metal increases, as shown in Fig. 6. This is mainly caused by the increase of residual austenite content in 

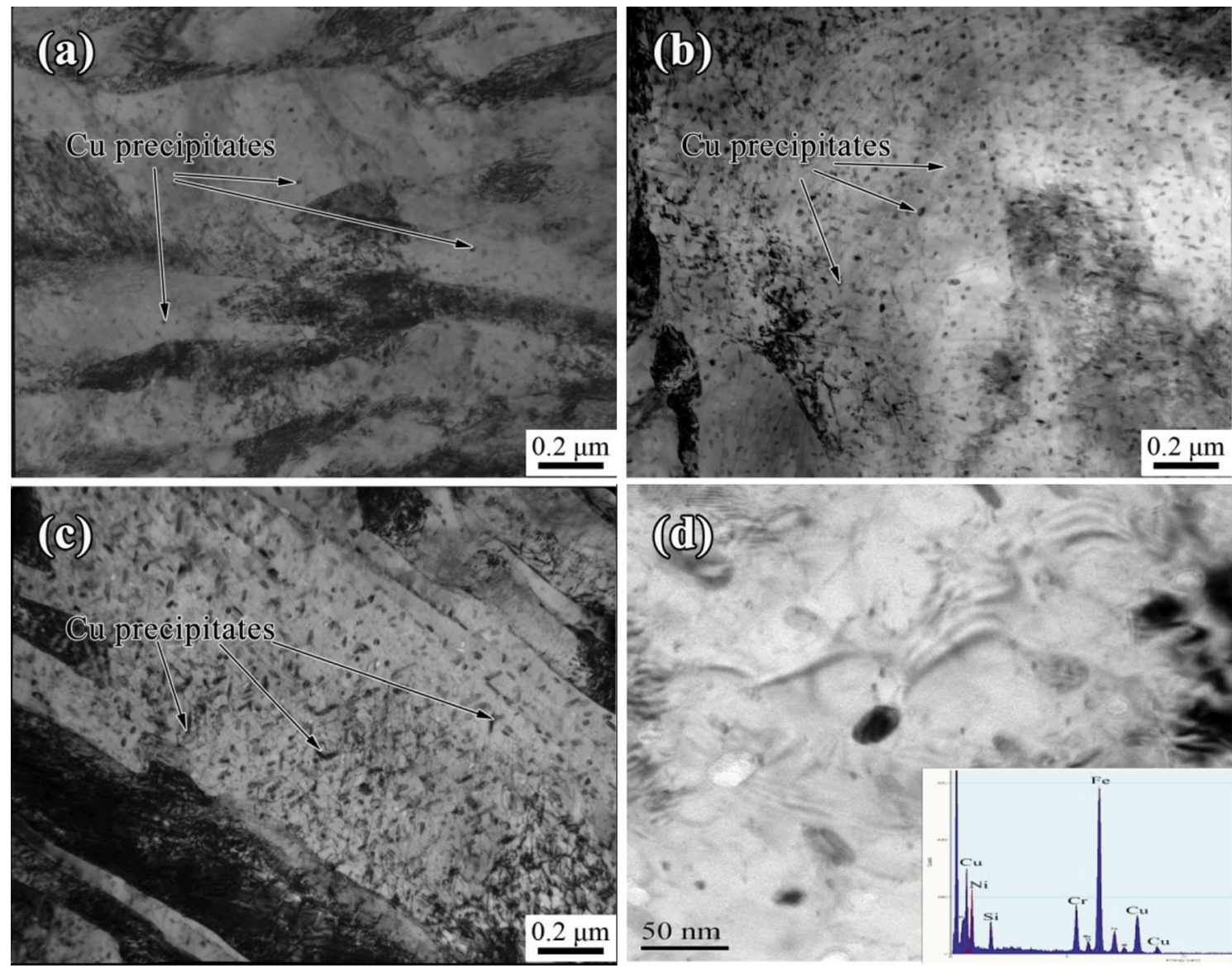

Fig. 4 TEM images and EDS analysis of Cu-rich phase of weld metal after aging-treated at $580{ }^{\circ} \mathrm{C}(\mathbf{a}), 600{ }^{\circ} \mathrm{C}(\mathbf{b})$ and $620{ }^{\circ} \mathrm{C}(\mathbf{c}),(\mathbf{d})$ for $4 \mathrm{~h}$

the tough phase, while the $\mathrm{Cu}$-rich phase, as the strengthening phase, has no positive effect on the toughness due to its aggregation and growth (Ref 26, 27). EBSD analysis shows that post-weld aging temperature $580{ }^{\circ} \mathrm{C}$ the austenite volume fraction is $0.1 \%$, which indicates martensite start happened reverse change to austenite (Fig. 4a and 5a), with the post-weld aging temperature rise of austenite formed through reverse change rapidly increase, the yield strength drops, so with the increase of post-weld aging temperature reverse change the amount of austenite increase gradually, gradually rising toughness and plasticity. With the increase of post-weld aging temperature, the internal stress of the tissue is released and the dislocation density decreases, which also play a positive role in the further improvement of toughness and plasticity.

Figure 7 and 8 show the central impact fracture morphology of three kinds of post-weld aging treatment welds. Figure 7 shows the SEM images of the impact crack initiation area of the weld. The SEM observation of the impact fracture morphology shows that the microcracks first sprout at the notch and stably expand to form a gray and dark fiber shape. After a certain distance of stable crack growth, the cracks lose stability and form a crystal shape. A large number of dimples are found in the fiber area, which is all broken in the way of micropore aggregation, as shown in Fig. 7. The results show that with the increase of post-weld aging temperature, the width of impact initiation zone increases obviously. When the post-weld aging temperature is $580{ }^{\circ} \mathrm{C}$, the minimum width of the crack initiation zone is $484.5 \mu \mathrm{m}$ (Fig. 7a); when the post-weld aging temperature is $600{ }^{\circ} \mathrm{C}$, the maximum width of the crack initiation zone is $1.2 \mathrm{~mm}$ (Fig. 7b); when the post-weld aging temperature is $620^{\circ} \mathrm{C}$, the maximum width of the crack initiation zone is $2.0 \mathrm{~mm}$ (Fig. 7c), and the plastic deformation zone is the largest. It can be seen that with the increase of postweld aging temperature, the width of crack initiation zone increases, which indirectly proves that the impact absorption energy of weld metal is increased by the generation of a large amount of reverse austenite at higher temperature post-weld aging treatment.

Figure 8 shows the fracture growth zone morphology of weld metal at three post-weld aging temperatures. It can be seen from Fig. 8(a), (b) and (c) that when the post-weld aging temperature is $580{ }^{\circ} \mathrm{C}$, the fracture morphology is a typical quasi-cleavage fracture. There are large quasi-cleavage steps and fan-shaped cleavage planes on the fracture, the surface of the growth zone tends to be flat, the river direction tends to be consistent, and the energy required for crack growth is reduced, as shown in Fig. 8(a). When the effective temperature is $600{ }^{\circ} \mathrm{C}$, the fracture surface shows quasi-cleavage and a small amount of tear edges composed of dimples. The river direction is complex, the size of cleavage surface is small, and more small facets appear. There are some tear edges between the small facets. The existence of small facets and tear edges improves the toughness of the sample (Ref 28), as shown in Fig. 8(b). When the post-weld aging temperature is $620^{\circ} \mathrm{C}$, the fracture surface shows quasi-cleavage and toughness. When dimples coexist, a certain amount of dimples and ductile tearing edges composed of dimples are distributed on the quasicleavage fracture surface. As shown in Fig. 8(c), the number of 

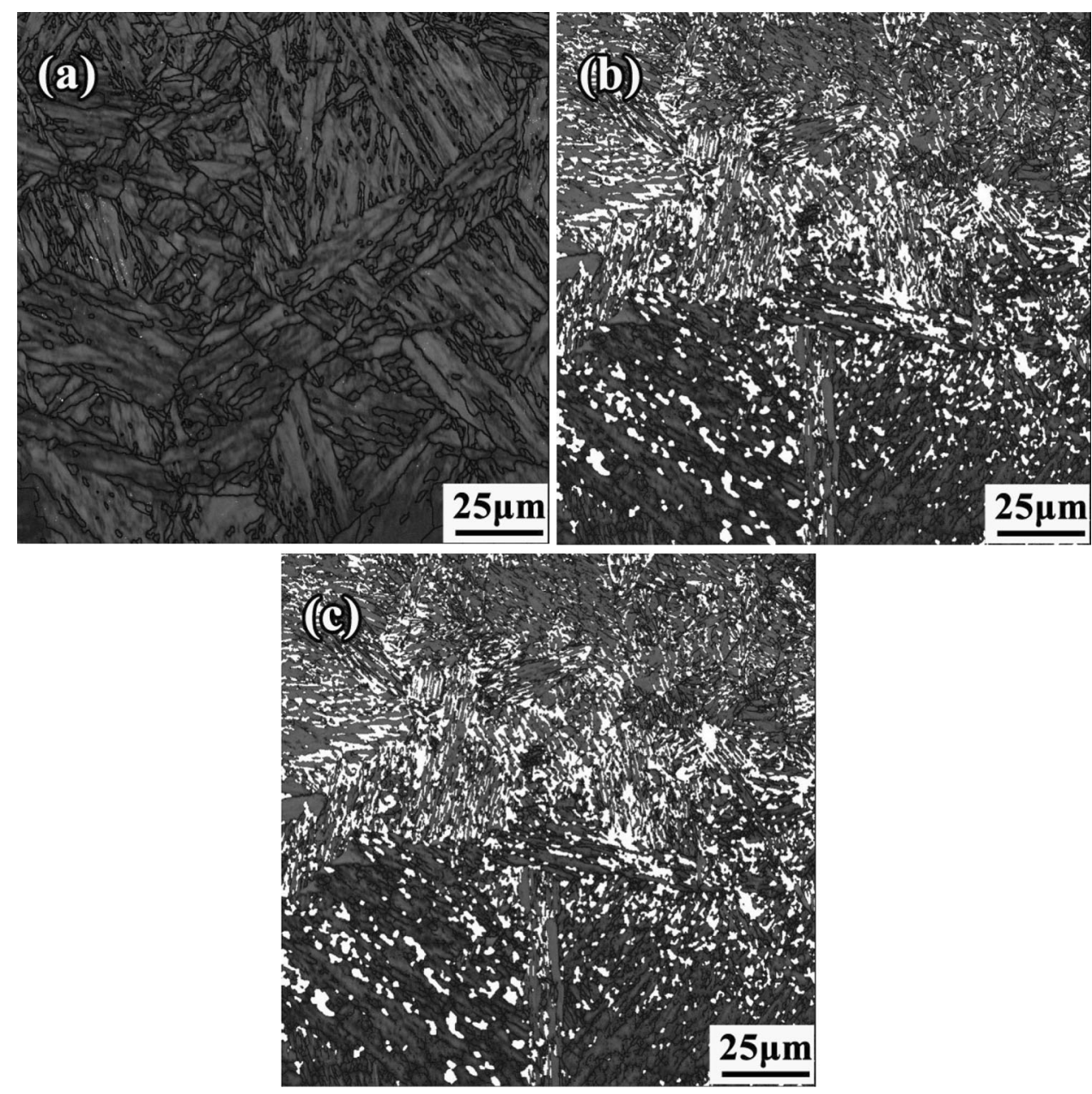

Fig. 5 Band contrast maps of EBSD of weld metal after aging-treated at $580{ }^{\circ} \mathrm{C}(\mathbf{a}), 600{ }^{\circ} \mathrm{C} \mathrm{(b)}$ and $620{ }^{\circ} \mathrm{C}(\mathbf{c})$

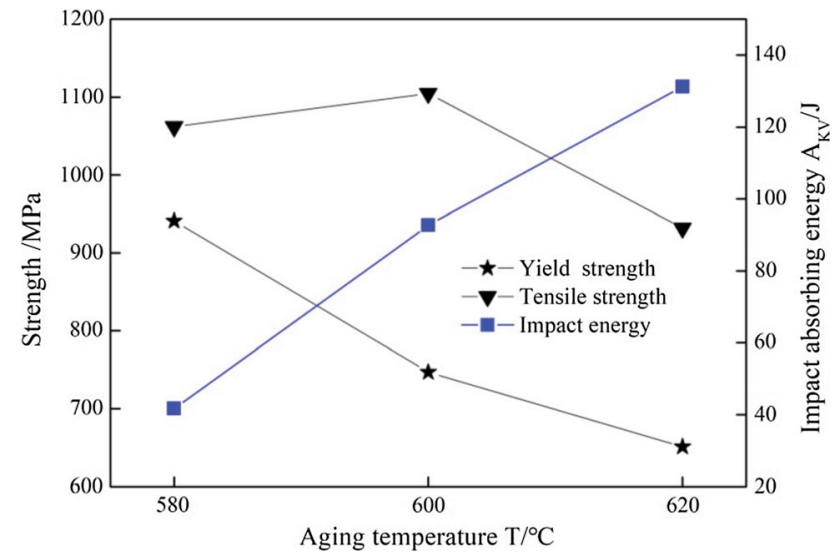

Fig. 6 Effect of aging temperature on properties

dimples or ductile tearing edges in the fracture also reflects the impact toughness value of the fracture, which also shows the reason for the high impact absorption energy when the postweld aging temperature is $620{ }^{\circ} \mathrm{C}$. It can be seen that with the increase of post-weld aging temperature, the fracture morphology changes from brittle fracture to mixed fracture (i.e., from quasi-cleavage + cleavage $\rightarrow$ quasi-cleavage + a $\quad$ small amount of dimples $\rightarrow$ dimples + a small amount of quasicleavage). The energy consumed in the process of crack growth increases gradually, and the change of impact fracture morphology is consistent with the impact energy absorbed by the weld.

\section{Conclusions}

The microstructure and mechanical properties of the $15-5 \mathrm{PH}$ stainless weld metals at different post-weld treatment were characterized. According to SEM and TEM analyses, when the post-weld aging temperature is $580{ }^{\circ} \mathrm{C}$, there is spherical copper-rich phase precipitation. With the increase of post-weld aging temperature, the copper-rich phase changes from coherent phase to non-coherent phase. At $620{ }^{\circ} \mathrm{C}$, the copper-rich phase is in short rod shape. The size of the precipitated $\mathrm{Cu}$-rich phase increases gradually, and the number increases first and then decreases. According to EBSD analysis, when the postweld aging temperature is $580{ }^{\circ} \mathrm{C}$, there is a small amount of austenite between the laths; that is, the reverse transformation of martensite to austenite occurs during post-weld aging treatment. With the increase of post-weld aging temperature, the content of austenite in the structure increases, and it 

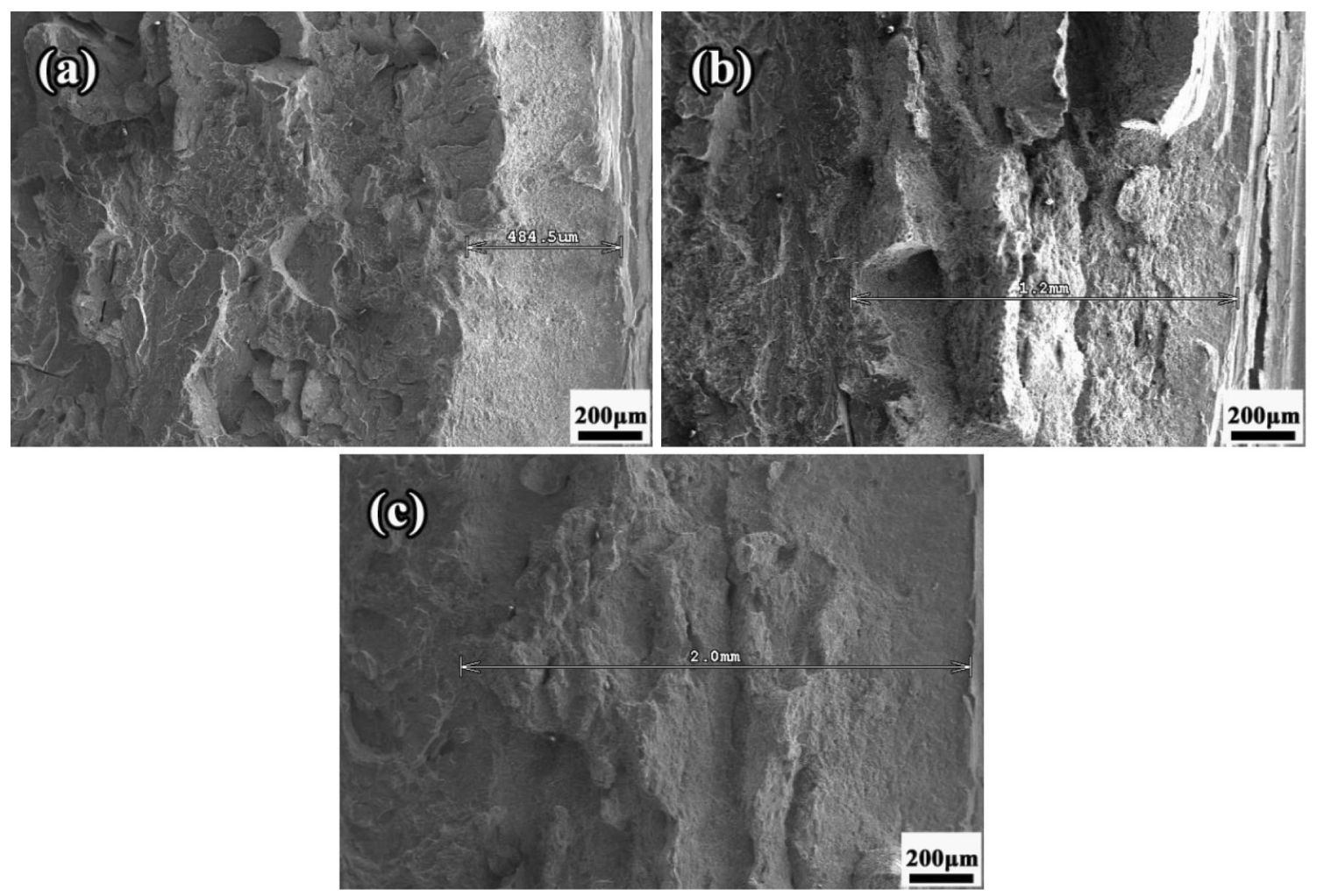

Fig. 7 The feature of crack origin area at different aging temperature $580{ }^{\circ} \mathrm{C}(\mathbf{a}), 600{ }^{\circ} \mathrm{C}(\mathbf{b})$ and $620{ }^{\circ} \mathrm{C}(\mathbf{c})$
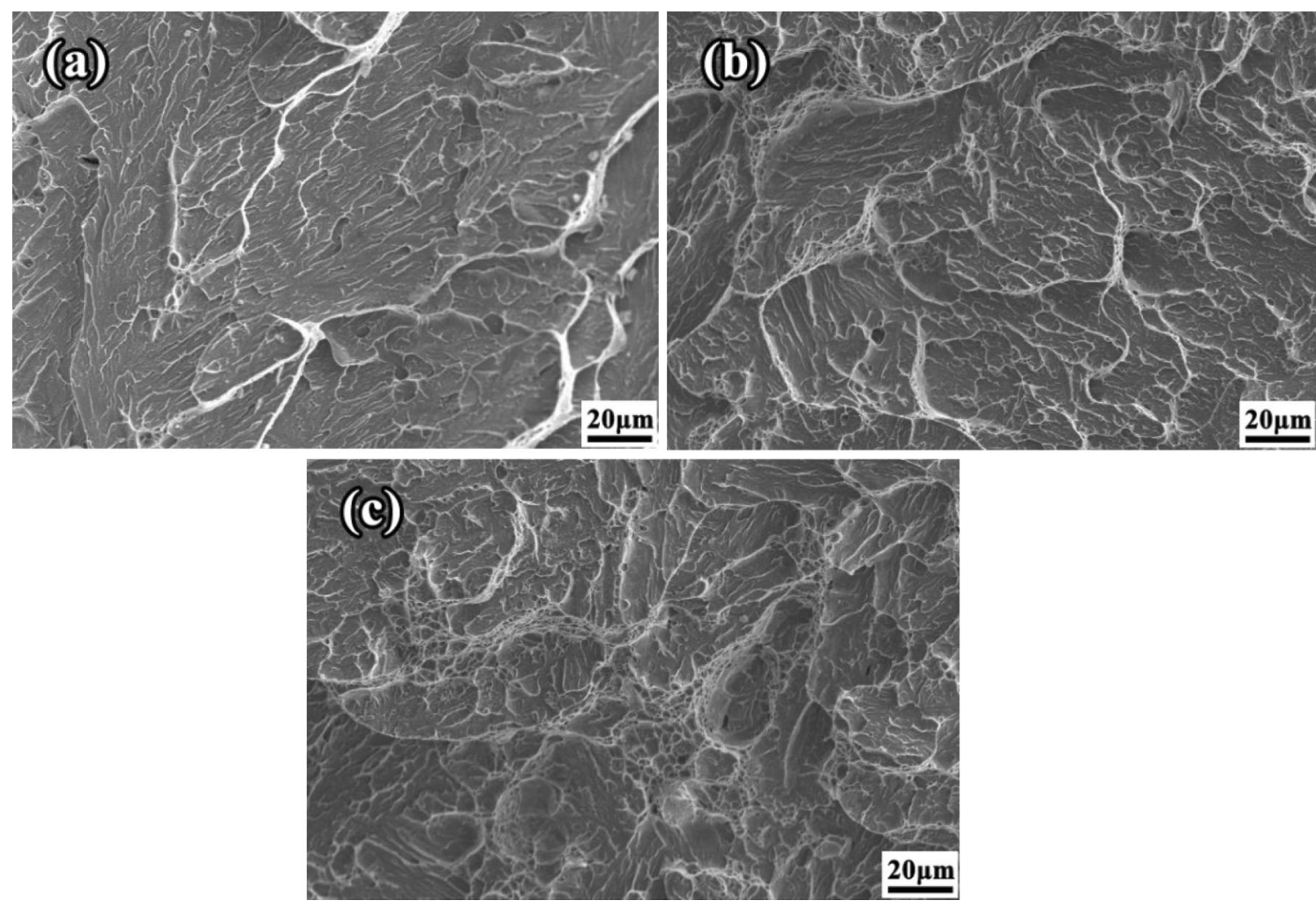

Fig. 8 The feature of crack propagation area at different aging temperature $580{ }^{\circ} \mathrm{C}(\mathbf{a}), 600{ }^{\circ} \mathrm{C}(\mathbf{b})$ and $620{ }^{\circ} \mathrm{C}(\mathbf{c})$

increases sharply when the temperature reaches $620^{\circ} \mathrm{C}$. With the increase of post-weld aging temperature, the tensile strength of weld metal increases first and then decreases, while the impact toughness increases. The former is mainly due to the size and distribution of copper-rich phase, and the latter is mainly due to the increase of reverse austenite content. 


\section{Acknowledgments}

This work is financially supported by Natural Science Foundation of Anhui Provincial Education Department (Nos. KJ2019A0061 and KJ2019A0069), the Opening Project of Anhui Province Key Laboratory of Metallurgy Engineering \& Resources Recycling (No. SKF19-04), State Key Laboratory of New Brazing Materials and Technology (No. SKLABFMT-201803), the Project National United Engineering Laboratory for Advanced Bearing Tribology (No. 201912) and Anhui Provincial Natural Science Foundation (Nos. 1908085QE198 and 2008085QE231).

\section{References}

1. K.H. Lo, C.H. Shek, and J.K.L. Lai, Recent Developments in Stainless Steels, Mater. Sci. Eng. R Rep., 2009, 65, p 39-104

2. H. Luo, Q. Yu, C.F. Dong, G. Sha, Z.B. Liu, J.X. Liang, L. Wang, G. Han, and X.G. Li, Influence of the Aging Time on the Microstructure and Electrochemical Behaviour of a 15-5PH Ultra-High Strength Stainless Steel, Corros. Sci., 2018, 139, p 185-196

3. X.Y. Peng, X.L. Zhou, X.Z. Hua, Z.W. Wei, and H.Y. Liu, Effect of Aging on Hardening Behavior of 15-5 PH Stainless Steel, J. Iron. Steel Res. Int., 2015, 22, p 607-614

4. H. Fayazfar, M. Salarian, A. Rogalsky, D. Sarker, P. Russo, V. Paserin, and E. Toyserkani, A Critical Review of Powder-Based Additive Manufacturing of Ferrous Alloys: Process Parameters, Microstructure and Mechanical Properties, Mater. Des., 2018, 144, p 98-128

5. M. Abdelshehid, K. Mahmodieh, K. Mori, L. Chen, P. Stoyanov, D. Davlantes, J. Foyos, J. Ogren, R. Clark, Jr., and O.S. Es-Said, On the Correlation Between Fracture Toughness and Precipitation Hardening Heat Treatments in 15-5PH Stainless Steel, Eng. Fail. Anal., 2007, 14, p 626-631

6. W.E. Frazier, Metal Additive Manufacturing: A Review, J. Mater. Eng. Perform., 2014, 23, p 1917-1928

7. A. Kumar, Y. Balaji, N.E. Prasad, G. Gouda, and K. Tamilmani, Indigenous Development and Airworthiness Certification of 15-5 PH Precipitation Hardenable Stainless Steel for Aircraft Applications, Sadhana, 2013, 38, p 3-23

8. U.K. Viswanathan, S. Banerjee, and R. Krishnan, Effects of Post-weld Aging on the Microstructure of 17-4 PH Stainless Steel, Mater. Sci. Eng. A, 1988, 104, p 181-189

9. P.J. Othen, M.L. Jenkins, and G.D.W. Smith, High-Resolution Electron Microscopy Studies of the Structure of $\mathrm{Cu}$ Precipitates in $\alpha$-Fe, Philos. Mag. A, 1994, 70, p 1-24

10. B. Yrieix and M. Guttmann, Post-weld Aging Between 300 and $450{ }^{\circ} \mathrm{C}$ of wrought martensitic $13-17 \mathrm{wt} . \% \mathrm{Cr}$ stainless steels, Mater. Sci. Technol., 1993, 9, p 125-137

11. L. Couturier, F. De Geuser, M. Descoins, and A. Deschamps, Evolution of the Microstructure of a 15-5PH Martensitic Stainless Steel During Precipitation Hardening Heat Treatment, Mater. Des., 2016, 107, p 416-425

12. Y.J. Lee, I.K. Lee, and S.C. Wu, Effect of Post-weld Heat Treatments on Microstructure and Mechanical Properties of Electron Beam Welded Flow Formed Marpost-Weld Aging Steel Weldment, Sci. Technol. Weld. Join., 2007, 3, p 266-273

13. N. Pettersson, S. Wessman, M. Thuvander, P. Hedström, J. Odqvist, R.F.A. Pettersson, and S. Hertzman, Nanostructure Evolution and
Mechanical Property Changes During Post-weld Aging of a Super Duplex Stainless Steel at $300{ }^{\circ} \mathrm{C}$, Mater. Sci. Eng. A, 2015, 647, p 241248

14. K. Yamamoto, Y. Kimura, F.-G. Wei, and Y. Mishima, Design of Laves Phase Strengthened Ferritic Heat Resisting Steels in Fe-Cr-Nb(-Ni) System, Mater. Sci. Eng. A, 2002, 329-331, p 249-254

15. S.S.M. Tavares, F.J. da Silva, C. Scandian et al., Microstructure and Intergranular Corrosion Resistance of UNS S17400 (17-4PH) Stainless Steel, Corros. Sci., 2010, 52, p 3835-3839

16. R. Badyka, G. Monnet, S. Saillet, C. Domain, and C. Pareige, Quantification of Hardening Contribution of G-Phase Precipitation and Spinodal Decomposition in Aged Duplex Stainless Steel: APT Analysis and Micro-hardness Measurements, J. Nucl. Mater., 2019, 514, p 266-275

17. P. Kochmanski and J. Nowacki, Influence of Initial Heat Treatment of 17-4PH Stainless Steel on Gas Nitriding Kinetics, Surf. Coat. Technol., 2008, 202, p 4834-4838

18. K.M. Aghaie and F. Adhami, Hot Deformation of 15-5 PH Stainless Steel, Mater. Sci. Eng. A, 2010, 527, p 1052-1057

19. J.A. Brooks and W.M. Garrison, Weld Microstructure Development and Properties of Precipitation Strengthened Martensitic Stainless Steels, Weld. J., 1999, 78, p 280-291

20. Z.B. Jiao, J.H. Luan, Z.W. Zhang, M.K. Miller, W.B. Ma, and C.T. Liu, Synergistic Effects of $\mathrm{Cu}$ and $\mathrm{Ni}$ on Nanoscale Precipitation and Mechanical Properties of High-Strength Steels, Acta Mater, 2013, 61, p 5996-6005

21. D. Palanisamy, P. Senthil, and V. Senthilkumar, The Effect of Postweld Aging on Machinability of $15 \mathrm{Cr}-5 \mathrm{Ni}$ Precipitation Hardened Stainless Steel, Arch. Civ. Mech. Eng., 2016, 16, p 53-63

22. H.R. Habibi-Bajguirani and M.L. Jenkins, High-resolution Electron Microscopy Analysis of the Structure of Copper Precipitates in a Martensitic Stainless Steel of Type PH 15-5, Philos. Mag. Lett., 1996, 73, p 155-162

23. R. Monzen, M.L. Jenkins, and A.P. Sutton, The bcc-to-9R Martensitic Transformation of $\mathrm{Cu}$ Precipitates and the Relaxation Process of Elastic Strains in an Fe-Cu Alloy, Philos. Mag. A, 2000, 80, p 711-723

24. H.R. Habibi Bajguirani, C. Servant, and G. Cizeron, TEM Investigation of Precipitation Phenomena Occurring in PH 15-5 Alloy, Acta Metall. Mater., 1993, 41, p 1613-1623

25. D. Isheim, M.S. Gagliano, M.E. Fine, and D.N. Seidman, Interfacial Segregation at $\mathrm{Cu}$ Rich Precipitates in a High-strength Low-carbon Steel Studied on a Sub-nanometer Scale, Acta Mater., 2006, 54, p 841849

26. T. Suzudo, Y. Nagai, D. Schwen, and A. Caro, Hardening in Thermally-Aged Fe-Cr Binary Alloys: Statistical Parameters of Atomistic Configuration, Acta Mater, 2015, 89, p 116-122

27. Y.M. Wang, T. Voisin, J.T. Mckeown, J. Ye, N.P. Calta, Z. Li, Z. Zeng, Y. Zhang, W. Chen, and T.T. Roehling, Additively Manufactured Hierarchical Stainless Steels with High Strength and Ductility, Nat. Mater., 2017, 17, p 63-71

28. B.C. Kim, S. Lee, N.J. Kim, and D.Y. Lee, Microstructure and Local Brittle Zone Phenomena in High-Strength Low-Alloy Steel Welds, Metall. Trans. A, 1991, 22, p 139-149

Publisher's Note Springer Nature remains neutral with regard to jurisdictional claims in published maps and institutional affiliations. 